\title{
The Dark Triad and Ethical Behavior
}

\author{
Windha Aprillia ${ }^{1}$, Satia Nur Maharani ${ }^{2 *}$
}

${ }^{1,2}$ State University of Malang
${ }^{*}$ Corresponding author. Email: satia.nur.fe@um.ac.id.

\begin{abstract}
The purpose of this paper is to examine the effect of the dark triad among Indonesia accountants on their ethical behaviour. Mach IV scale is used to measure the Machiavellianism traits of accountants, the NPI-16 scale is used to assess the Narcissism traits, and PPI scale is used to measure the Psychopathy traits. This approach used 26 public accountant firms in Malang, Surabaya and Jakarta for a sample. We expect that the result of Machiavellianism has a negative influence on ethical behaviour. On other hand, we expect Narcissism and Psychopathy has a positive influence on ethical behaviour. The paper finds out that narcissism, and psychopathy have a positive influence on ethical behaviour, while Machiavellianism has a negative influence on ethical behaviour.
\end{abstract}

Keywords: Machiavellian, Narcissism, Psychopathy, Ethical Behavior

\section{INTRODUCTION}

This study examines the effect of the dark triad nature on ethical behaviour in Indonesian public accountants (Malang, Surabaya and Jakarta). Ethical behaviour becomes a crucial, with the large number of individuals involved in unethical behaviour scandals (Palomino, et. al., 2018; Tonge, et. al., 2003; Vandekerckhove, 2019; Wright, 2014). Behavioural research on current ethicsbased problems has focused on the scope of the accountant profession from national accounting firms as well as international (Sr \& Virginia, 2013). However, research discussing the psychological perspective of accountants is still lack. Thus far, people consider accountants as someone who has superior qualifications in checking the fairness of the companies' financial statements. Accountants have an obligation to increase the credibility of financial statements as well as provide an assurance for investment company. This indicates that accountants have a responsibility to carry the mandate behave ethically in audit activities. Apparently, there is a growing concern regarding the ethical behaviour of accountants, which is marked by rampant cases of license suspension and revocation to practice (W. E. Shafer \& Simmons, 2008).
Regarding the accounting profession being a mere material field has long been debated (Citron, 2003), which leads to an increasing of "crisis of confidence" in the public accounting profession. From day to day, ethical problems ranging from market manipulation to fraud continue to increase rapidly. A recent study regarding fraud by ACFE (Association of Certified Fraud Examiners) in 2018 stated that there was more than 2690 cases of fraud with a total loss more than $\$ 1$ million (Association Of Certified Fraud Examiners, 2018). Unethical behaviour by accountants is reflected in the case happened to PT Great River International (GRI) in 2007 which is involving public accountant Justinus Aditya Sidharta. Another fraud case occurred at PT. Muzatek Jaya in 2004, public accountant Petrus Winata took part in this scandal.

Paulhus (2002) examined the nature of Narcissism, Machiavellian and Psychopaths called dark triad. Dark triad is a term referring to a combination of three psychological traits that are considered determinants of behaviour that tends to be selfish and manipulative (Franco de Lima \& D'Souza, 2015). Researches conducted by Johnson, et. al (2013) \& Murphy (2012) proved that individuals dark triad associated with financial statement fraud. This also proven in researches conducted by Campbell, et. al (2004) \& Jain \& Bearden (2011) that dark triad individuals have high self- 
confidence excessive and more willing to face big risks in decision making. The last is research conducted by Jones (2013), which states that dark triad individuals tend to be involved in embezzling money for personal gain.

This study presents a nature of dark triad from a different perspective. In this study, it is expected that individuals who have a dark triad are capable to lead the companies to success and have a commitment in doing something ethically. All assumptions in this study based on relevant and credible previous researches. The formulation of research problems are presented below:

1. Does Machiavellian have a negative and significant effect on accountants' ethical behaviour?

2. Does Narcissism have a positive and significant effect on accountants' ethical behaviour?

3. Does psychopathy have a positive and significant effect on the ethical behaviour of accountants?

\section{LITERATURE REVIEW}

TPB is an abbreviation of Theory Reasoned Action (TRA) proposed by Ajzen \& Fishbein (1975), it includes dimensions of attitudes and subjective norms as indicators in determining an intention to perform behaviour (Kan, et. al, 2017). TRA still becomes a global issue to be discussed as a model in order to understand and predict behaviour related to individual psychology (Cappella, 2008; Mullen, et. al, 1987). However, TRA is limited by the assumption that behaviour is completely under individual control. In responding this idea, Ajzen (1985) in Yzer (2017) conducted a meta-analysis study by refining the TRA theory into TPB to overcome the obstacles that occur in TRA by adding one dimension of intention, namely perceived of behavioural control (Ajzen \& Driver, 1991). Ajzen divided the TPB dimension into three beliefs, namely behavioural beliefs, establishing attitude variables related to individual beliefs about the impact of performed behaviour, normative belief which forms the subjective norm variable related to belief individuals regarding the opinions of others in considering performance behaviour, and control belief which forms the variable perceived behavioural control which is individuals perception regarding how big the impact of that behaviour (Ajzen, 2002).

Ethics is a key component determining how individuals behave (Perry, 2015). Ethics' definition is divided into three definitions. First, ethics is a moral value as an individual guide. Second, ethics is manifested in the form of a set of principles or code of ethics. Third, ethics is said to be a science of good and bad. Another research reveals the factors influencing accountants in ethical behaviour include ethical climate, professional commitment, corporate ethical value, and ethical ideology (W. E. Shafer, 2009; Shafer \& Simmons, 2008; Shafer et al., 2018; Shafer \& Roselyn, 2001). In Indonesia, ethical standards which regulates behaviour norms among accountants to their clients and partners are made by the Indonesian Institute of Accountants (IAI).

\subsection{Machiavellianism}

Machiavellianism is a person's social behaviour that leads to the manipulation other individuals for personal gain (Paulhus, 2002). Research conducted by Smith, et. al (2009) found that employees in non-profits with high Machiavellian traits were less likely to have questionable behaviour. Shafer and Simmons (2008) found that Machiavellian positively related to tax accountant ethics in the aspect of tax avoidance. Research conducted by Shafer \& Wang, et. al (2014) proved that Machiavellian also affects employees' behaviour in the banking sector Based on the explanation, the following hypothesis is formulated.

H1. Machiavellian has a negative and significant effect on ethical behaviour.

\subsection{Narcissism}

According to Paulhus (2002) in Hobson (2019), the nature of narcissism is self-admiration, selfishness, arrogant, but persistent, never gives up, and adaptable. Wales, et. al (2013) stated that individuals with a high Narcissism orientation tend to have a soul better leadership, compared to individuals who have a low narcissism. Overconfidence character in narcissism individuals is proven to bring success to the organization (Benmelech \& Frydman, 2014). Narcissistic 
individuals are also synonymous with high optimism and self-esteem.

In an economic context, high optimism and selfesteem play a role in strengthening accountants' self-defence against social influences that come from outside organization, such as the pressure from a client to perform unethical behaviour during audit work (Furnham, et. al, 2013). When dealing with clients, accountants with high levels of narcissism are exactly good at creating a good impression (Hart, et. al., 2016). Accountants with high narcissism are also synonymous "Happy Face" (Rose, 2002) to attract clients' attention in order to increase clients' belief. Based on the explanation, the following hypothesis is formulated:

H2. Narcissism has a positive and significant effect on ethical behaviour

\subsection{Psychopath}

Psychopathy is a personality disorder whose main characteristic is an outward sense of self-worth usual with a lack of guilt, conscience and empathy (Paulhus, 2002; Maibom, 2005). Almost every large corporation has an organizational psychopath working for them (Jepessen \& Leder, 2016). Egocentrism, impulsivity, and a lack of empathy are some of the characteristics of the psychopathic individual (Franco de Lima, 2015). On the one hand, the dominant trait of a psychopathic individual can positively improve accountants performance (S. F. Smith \& Lilienfeld, 2013).

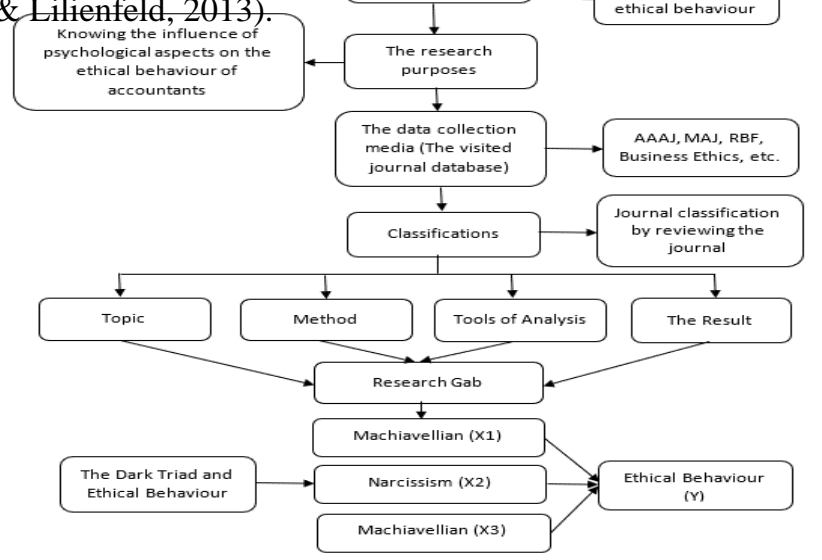

Babiak, et. al, (2014) proved that high psychopath individuals tend to be overconfidence, ambitious, never give up, and dare to take high risks. They are synonymous with style unique leadership that is often chosen as a promising leader candidate high success. Also, it is proven that they hold superior positions in every organization (Jones, 2013). Pletti, et. al, (2017) stated that individual who have psychopaths are willing to sacrifice everything for achieving goals. They are experts in dealing with behavioural dilemmas that befall them. Individual Psychopath has a very strict nature. This trait is one of indicators of its height quality of corporate leadership. The leadership abilities can spread positive vibes to people around them. This ability believed to be able to help other individuals to achieve a success. Based on the explanation, the following hypothesis is formulated:

H3. Psychopathic has a positive and significant effect on Ethical Behaviour

\section{RESEARCH METHOD}

\subsection{Research design}

This research used quantitative to examine the effect of independent variables on variables dependent. We build research designs to facilitate the comprehension of research. It is shown in figure

3.1 .
Figure 3.1. Research Design 3.2. Research Instruments
Respondents were required to fill in the Ethical Behaviour, Machiavellianism, Narcissism and 
Psychopathic instruments. The instrument was used to measure ethical behaviour among Indonesian accountants. This instrument includes 10 statement items. Responses were given on a five-point scale consisting of "strongly disagree" (1) and "strongly agree" (5). This instrument has been widely used in the study of ethical behaviour (Rest, 1984).

The Machiavellianism scale called Mach IV (Christie \& Geis, 1970) is also a widely used instrument, having been adopted in many business and social science studies. The scale includes three indicators with a design of 9 statements to measure Machiavellian tendencies. Responses were given on a five-point scale consisting of "strongly agree" (1) and "strongly disagree" (5), with higher numbers indicating a greater propensity to Machiavellianism.

Narcissism was assessed by using the Raskin \& Hall (1981) instrument, namely the NPI-16, which includes three indicators for 12 statements. This instrument is a measure of narcissism that is most widely used in social or personality psychology since its early development. We adopted a fivepoint scale covering "strongly disagree" (1) and "strongly agree" (5). Finally, Psychopath was assessed by using the Lilienfield \& Andrews (1970) instrument, namely the PPI (S. F. Smith \& Lilienfeld, 2013), which includes eight indicators for 11 statements. This instrument is designed to comprehensively assess the personality types associated with psychopaths.

\subsection{Sampling and Data Collection}

The target population in this study is the Public Accounting Firms (KAP) in Malang, Surabaya and Jakarta. Purposive sampling technique was used in this study. Therefore, KAP was chosen, which was registered with IAPI. Overall, the sample consists of 19 firms participating in this study. The independent variables of this study are the nature of Machiavellianism, Narcissism, and Psychopathy, while Ethical Behaviour is the dependent variable.

\subsection{Analysis Technique}

Before distributing the questionnaire, validity and reliability test were conducted earlier to determine the quality of research data. Then, conducting an assumption classic test to detect all assumptions in the multiple regression model and facilitate the data interpretation and analysis processes. The classic assumption test includes multicollinearity test, heteroscedastic test, and normality test. Further, analysing the research data by using multiple linear regression and testing the hypotheses to find out whether the three independent variables significantly influence an ethical behaviour. The hypotheses supported empirically if the probability under 0.05 .

\section{RESULTS AND DISCUSSION}

\subsection{Overview of Research Objects}

The object of this study is public accounting firms (KAP) in Malang, Surabaya and Jakarta. The selected companies which being a sample is Non Big-four KAP. Data collection was carried out by distributing research questionnaires directly. There are 140 respondents who received the questionnaire. However, as many as 57 questionnaires did not get feedback. There are 107 questionnaires being processed in this study. Table 4.1 below shows the profile of the respondents in this study: 
Table 1. Profile of Respondents

\begin{tabular}{|c|c|c|c|c|c|}
\hline & & Frequency & Percent & $\begin{array}{c}\text { Valid } \\
\text { Percent }\end{array}$ & $\begin{array}{c}\text { Cumulative } \\
\text { Percent }\end{array}$ \\
\hline \multicolumn{6}{|l|}{ Gender } \\
\hline \multirow{3}{*}{ Valid } & Man & 82 & 76,6 & 76,6 & 76,6 \\
\hline & Woman & 25 & 23,4 & 23,4 & 100 \\
\hline & Total & 107 & 100 & 100 & \\
\hline
\end{tabular}

\section{Work}

Experience

\begin{tabular}{|c|c|c|c|c|c|}
\hline & $<1$ Year & - & - & - & - \\
\hline & 1-3 Year & 73 & 68,2 & 68,2 & 68,2 \\
\hline \multirow[t]{3}{*}{ Valid } & 3-5 Year & 34 & 31,8 & 31,8 & 100 \\
\hline & $>5$ Year & - & - & - & - \\
\hline & Total & 107 & 100 & 100 & \\
\hline
\end{tabular}

\section{Education}

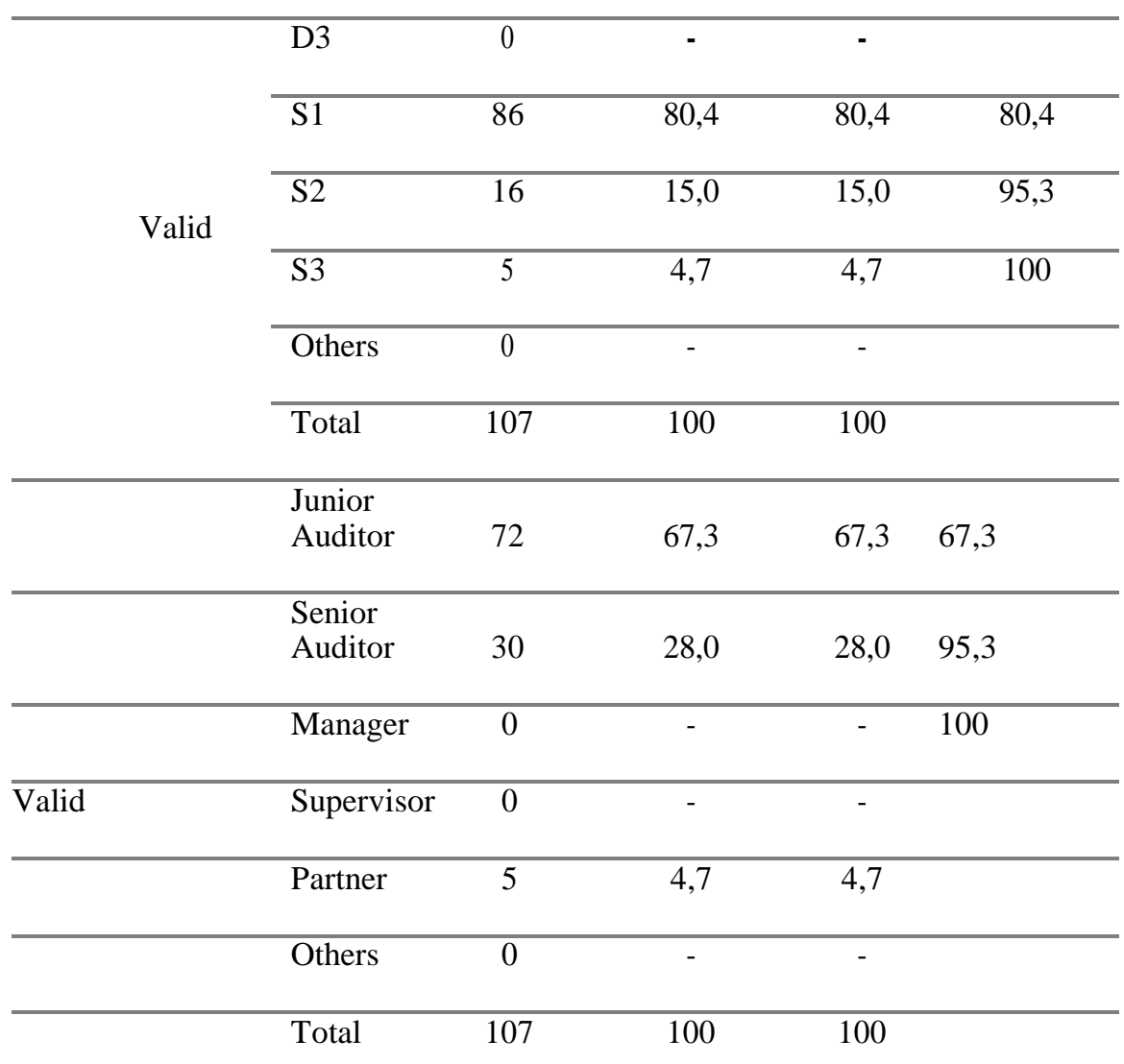

The Assignment 


\begin{tabular}{|c|c|c|c|c|c|}
\hline & $\begin{array}{l}>10 \\
\text { Assignment }\end{array}$ & 0 & 0 & - & - \\
\hline & $\begin{array}{l}8-10 \\
\text { Assignment }\end{array}$ & 4 & 3,7 & 3,7 & 100 \\
\hline \multirow[t]{3}{*}{ Valid } & $\begin{array}{l}4-7 \\
\text { Assignment }\end{array}$ & 34 & 31,8 & 31,8 & 96,3 \\
\hline & $\begin{array}{l}1-3 \\
\text { Assignment }\end{array}$ & 69 & 64,5 & 64,5 & 64,5 \\
\hline & Total & 107 & 100 & 100 & \\
\hline
\end{tabular}

Table 1 provides information that 82 respondents $(76.6 \%)$ are man, while 25 respondents $(23.4 \%)$ are woman. There are $68.2 \%$ of respondents have worked experience for 1-3 years. Then, as many as 86 respondents $(80.4 \%)$ have undergraduate educational backgrounds, the rest have S2 and doctoral educational backgrounds. There are 72 respondents $(67.3 \%)$ who have a position as junior auditor and 30 respondents $(28.0 \%)$ have a position as senior auditor. Finally, 69 respondents (64.5\%) have an average number of assignment 1-3 tasks. 34 respondents $(31.8 \%)$ have an average number of assignments of 4-7 tasks, and 4 respondents (3.7\%) have an average number of assignments of 8-10 tasks.

\subsection{Hypothesis Test Results 1}

Hypothesis 1 predicts that accountants who have a high Machiavellian trait tend to behave unethically. These hypotheses were tested by using multiple linear regression method. Table 2 below shows the results of hypothesis testing 1 .

Table 2. Hypothesis Test Results 1

\begin{tabular}{|c|c|c|c|c|c|}
\hline \multirow[t]{2}{*}{ Model } & \multicolumn{2}{|c|}{$\begin{array}{c}\text { Unstandardized } \\
\text { Coefficients }\end{array}$} & \multirow{2}{*}{$\begin{array}{c}\text { Standardized } \\
\text { Coefficients }\end{array}$} & \multirow[t]{2}{*}{$t$} & \multirow[t]{2}{*}{ Sig. } \\
\hline & B & Std. Error & & & \\
\hline $\mathrm{X}_{1}$ & $-0,171$ & 0,066 & $-0,243$ & $-2,590$ & 0,011 \\
\hline
\end{tabular}

Table 2 shows that Machiavellian behaviour has a negative effect on ethical behaviour. This is indicated by a p-value of $0.011<0.05$ and the coefficient is negative, which means that Machiavellian has a negative effect on ethical behaviour. Thus, H1 which states that Machiavellian negatively affects ethical behaviour cannot be rejected. This indicates that the Machiavellian nature of accountants (who were involved as respondents in this study) influences ethical behaviour in doing their work. Accountants who have a high Machiavellian orientation tend to behave unethically (Palomino, et. al., 2018). In contrast, accountants who have a low Machiavellian orientation will behave more ethically (Dalton \& Radtke, 2019). The results of this study are consistent with previous studies conducted by P. C. Smith, et. al (2009), Triki (2017), Shafer et al. (2018), Palomino, et. al. (2018), Dalton, et. al. (2019), and Utami, (2019) which state that accountants who have a high Machiavellian tend to behave unethically.

The results of this study are also in line with the Theory planned behaviour (TPB), which states that an accountants' unethical behaviour arises because they have confidence in the availability of resources and opportunities to carry out this behaviour. This belief is closely related to the accountants' intention to commit unethical behaviour (Murugesan \& Jayavelu, 2015). Accountants with a high Machiavellian belief that 
it is easier to decide to behave less ethically (Shafer, et. al., 2018).

\subsection{Hypothesis Test Results 3}

Hypothesis 3 predicts that accountants with a high Psychopath orientation are able to commit to Table 3. Hypothesis Test Results 3 ethical behaviour. Hypothesis 3 was tested by using multiple linear regression method. Table 4.4 shows the results of the third hypothesis test in this study.

\begin{tabular}{lccccc}
\hline \multirow{2}{*}{ Model } & $\begin{array}{c}\text { Unstandardized } \\
\text { Coefficients }\end{array}$ & $\begin{array}{c}\text { Standardized } \\
\text { Coefficients }\end{array}$ & $t$ & Sig. \\
\cline { 2 - 4 } & $\boldsymbol{B}$ & Std. Error & Beta & & \\
\hline $\mathrm{X}_{3}$ Psychopathy & 0,151 & 0,063 & 0,221 & 2,394 & 0,018 \\
\hline
\end{tabular}

Table 3 shows that the nature of psychopath has a positive effect on ethical behaviour. It is proven by the significance value of the Narcissism variable which has a p-value of $0.018<0.05$ and the coefficient is positive, which means that psychopath has a positive effect on ethical behaviour. Thus, H3 which states that Psychopath has a positive effect on ethical behaviour cannot be rejected. Although some studies suggest that psychopath individuals cause adverse effects on organizational survival. Babiak, et. al (2014) proved that accountants with high psychopath tend to be overconfidence, ambitious, never give up, and dare to take high risks. They are experts in dealing with behavioural dilemmas that befall them compared with individuals who have a low psychopathic. Their ability in solving problems shows that they are very creative and innovative, full of care to solve the problem of behavioural dilemmas (Harms \& Wood, 2016).

This results of the study support other studies conducted by Mahaffey \& Marcus (2006), Babiak (2010), Glover et al. (2010), Osumi \& Ohira (2010), Caruso \& Gino (2011), Jonason et al. (2012), Furnham et al. (2013), Jones (2013), Amernic et al. (2016), Sandvik et al. (2014), Boddy (2007a; 2015b), Clive Roland Boddy \& Taplin (2016), Harms \& Wood (2016), Ak, Amil, \& Mahmut (2016), Tucker et al. (2016), Anderson \& Cheers (2017), Pletti et al. (2017), Paleczek et al. (2018), Henfrey (2018), Anthony \& Prusik (2019), Hill \& Scott (2019), and Veres et al. (2019), which state that the Psychopath always manages to face ethical dilemmas during the course of their audit work. The ambitious attitude that exists in psychopath accountants is balanced with an unyielding attitude embedded in their personality, so their clients' problem can be solved by them in a good way. This result also support the theory of planned behaviour concept (TPB) which states that accountants' decision in behaving is determined by the social pressure they feel (Ajzen, 1991). The accountants perform that kind of behaviour because people around them think that that behaviour is legal (Young, et. al, 1991).

\section{CONCLUSIONS}

Do not judge book by its cover, Mark Manson, in his book The subtle of not giving a $f^{* * * k}$ teaches that as an ordinary people who are full of shortcomings, we do not have to always look positive in front of others. This research proves that psychological traits, which are considered negative and tend to be disliked, actually bring blessings to the organization it shelters. That is why researchers are emphasized not to underestimate when try to understand the dark triad personality.

Based on the data analysis that has been done, the following conclusions can be drawn as:

1. Machiavellian nature has a negative and significant effect on accountants' ethical behaviour, so that $\mathrm{H} 1$ cannot be rejected. Accountants who have a high Machiavellian orientation have a higher chance of behaving unethically. 
2. Narcissism has a positive and significant effect on the ethical behaviour of accountants, so $\mathrm{H} 2$ cannot be rejected. Accountants who have a high Narcissism orientation tend to behave ethically. This is because they use overconfidence in their souls as a shield against social stimuli that can lead them to unethical behaviour.

3. The nature of psychopathy has a positive and significant effect on the ethical behaviour of accountants, so that $\mathrm{H} 3$ cannot be rejected. Accountants who have a high psychopathic orientation tend to behave ethically. This is caused by a very strong ability. Accountants with high psychopathic traits are able to withstand any threat.

The limitation of this study is, firstly, this study only describes the phenomena in the form of questionnaire. Although the researchers have tried their best to reduce bias, the results of the study have not fully described the phenomenon of the conditions that occur in the object of research. This limitation is very common in quantitative research with primary data. Second, the questionnaire items in this study use international journal references. There is a possibility of misinterpretation from both the researcher and the respondent. Third, the respondents in this study were only limited to KAPs domiciled in Malang City, Surabaya City, and Jakarta City and were included in the Non BigFour KAP. This is due to the lack of relationship between researchers and Big-Four KAP and lack of opportunities to be able to distribute questionnaires to Big-Four KAP. Time and cost limitations are also the reasons for the limitations of this study. It is feared that this will not be able to represent the real population situation in the field.

Furthermore, future research must be able to describe the phenomena in the field more clearly and completely. This can be done by digging deeper with interviews and using a qualitative approach to obtain clearer and more complete information. Further research should expand the scope of research to the scope of Big-Four KAP to see the implementation of the dark triad nature of accountants who work in Big-Four KAP. A comparative study examining the role of the Dark Triad between KAP Non-Big-Four and KAP Big-
Four can be an alternative for further research in the future.

\section{REFERENCES}

[1]. Ajzen, I. (1985). The Theory of Planned Behaviour. Quintessenz Journal, 15(10), 909-914.

Doi: 10.4135/9781446249215.n22.

[2]. Ajzen, I. (2002). Perceived behavioural control, self-efficacy, locus of control, and the theory of planned behaviour. Journal of Applied Social Psychology, 32(4), 665-683. Doi:10.1111/j.15591816.2002.tb00236.x.

[3]. Ajzen, I., \& Driver, B. L. (1991). Prediction of leisure participation from behavioural, normative, and control beliefs: An application of the theory of planned behaviour. Leisure Sciences, 13(3), 185-204. Doi: 10.1080/01490409109513137.

[4]. Ajzen, I., \& Fishbein, M. (1975). Belief, attitude, Intention, and Behaviour: An introduction to theory and research. Massachusetts: Adison-Wesley.

[5]. Ak, M., Amil, O., \& Mahmut, Ö. (2016). Is your manager a psychopath? An evaluation of the relationship between the personality types of managers and workers and the levels of psychopathy. Social and Behavioural Sciences, 221, 76-85.

Doi:10.1016/j.sbspro.2016.05.092.

[6]. Amernic, J. H., \& Craig, R. J. (2016). Accounting as a facilitator of extreme narcissism linked references are available on JSTOR for this article: Accounting as a facilitator of extreme. Journal of Business Ethics, 96(1), 7993. Doi:10.1007/s10551-010-0450-0.

[7]. Anderson, J., \& Cheers, C. (2017). Does the dark triad predict prejudice? The role of machiavellianism, psychopathy, and narcissism in explaining negativity toward asylum seekers. Australian 
Psychological Society, 55(3), 271-281. Doi:10.1111/ap.12283.

[8]. Anthony, M., \& Prusik, M. (June, 2019). The relationship between the dark triad personality traits, motivation at work, and burnout among $\mathrm{hr}$ recruitment workers. Frontiers in Psychology. Doi: 10.3389/fpsyg.2019.01290.

[9]. Association of Certified Fraud Examiners. (2018). Global study on occupational fraud and abuse.

[10]. Babiak, P. (2010). Corporate psychopathy: Talking the walk. Behavioural Sciences \& the Law, 28(2), 211-223. Doi: 10.1002/bsl.

[11]. Benmelech, E., \& Frydman, C. (2014). Military CEOs. Journal of Financial Economics, 117(1), 43-59. Doi: 10.1016/j.jfineco.2014.04.009.

[12]. Bernardo, A. E., Welch, I., \& Haven, N. (2001). On the evolution of overconfidence and entrepreneurs. Journal of Economics \& Management Strategy, 10(3), 301-330.

[13]. Boddy, C. R. (2015). The implications of corporate psychopaths for business and society: An initial examination and a call to arms. AJBBS, 1(2), 30-40.

[14]. Boddy, C. R. (2007). The dark side of management decisions : Organisational psychopaths. Management Decision, 44(10), 14611475.

Doi:10.1108/00251740610715759.

[15]. Boddy, C. R., \& Taplin, R. (2016). The influence of corporate psychopaths on job satisfaction and its determinants. International Journal of Manpower, 37(6), 965-988. Doi: 10.1108/IJM-122015- 0199.

[16]. Buchholz, F., Jaeschke, R., Lopatta, K., \& Mass, K. (2018). The use of optimistic tone by narcissistic CEOs. Accounting, Auditing \& Accountability Journal, 31(2), 531-562. Doi: 10.1108/AAAJ-112015-2292.
[17]. Campbell, W. K., Goodie, A. S., \& Foster, J. D. (2004). Narcissism , confidence, and risk attitude. Journal of Behavioural Decision Making, 17, $297-$ 311.

[18]. Christie, R., \& Geis, R. L. (1970). Studies in Machiavellian. Massachusetts: Academic Press.

[19]. Campbell, W. K., Reeder, G. D., Sedikides, C., \& Elliot, A. J. (2000). Narcissism and comparative selfenhancement strategies. Journal Research in Personality, 34(3), 329-347. Doi: $10.1006 /$ jrpe.2000.2282.

[20]. Cappella, J.N. (2008). Planned Behavior, Theory of. In The International Encyclopedia of Communication, W. Donsbach (Ed.). https://doi.org/10.1002/9781405186407. wbiecp040.

[21]. Caruso, E. M., \& Gino, F. (2011). Blind ethics: Closing one's eyes polarizes moral judgments and discourages dishonest behaviour. Cognition, 118(2), 280-285.

Doi:10.1016/j.cognition.2010.11.008.

[22]. Chatterjee, A., \& Hambrick, D. C. (2011). Executive personality , capability cues, and risk taking: How narcissistic CEOs react to their successes and stumbles. Administrative Science Quarterly, 56(2), 202-237. Doi:10.1177/0001839211427534.

[23]. Church, B. K. (1911). The role of auditor narcissism in auditor-client negotiations: Evidence from China. Contemporary Accounting Research, 37(3), 1756-1787. Doi: 10.1111/19113846.12565 .

[24]. Citron, D. B. (2003). The UK $s$ framework approach to auditor independence and the commercialization of the accounting profession. Accounting, Auditing \& Accountability Journal, $\quad$ 16(2), 244-274. doi:10.1108/09513570310472067. 
[25]. Cohen, J., Ding, Y., Lesage, C., \& Stolowy, H. (2010). Corporate fraud and managers' behaviour: Evidence from the press. Journal of Business Ethics, 95(SUPPL. 271-315. doi:10.1007/s10551-011-0857-2.

[26]. Dalton, D., \& Radtke, R. R. (2019). The joint effects of machiavellianism and ethical environment on whistleblowing. Journal of Business Ethics, 117(1), 153-172. Doi:10.1007/s10551012-1517-x.

[27]. Delroy, L., Paulhus, K. M. W. (2002). The dark triad of personality: Narcissism, machiavellianism, and psychopathy. Journal of Research in Personality, 36, 556-563. doi:10.1007/978-3-319-98446-9_43.

[28]. Franco de Lima, G. A. S., \& D'Souza, M. F. (2015). The dark side of power: The dark triad in opportunistic decisionmaking. Journal of Advances in Scientific and Applied Accounting, 8(2), 135-156.

Doi:

10.14392/ASAA.2015080201.

[29]. Furnham, A., Richards, S. C., \& Paulhus, D. L. (2013). The dark triad of personality: A 10 Year Review. Social and Personality Psychology Compass, 7(3), 199-216.

[30]. Glover, N., Mullins-Sweatt, S. N., Glover, N. G., Derefinko, K. J., \& Miller, J. D. (2010). The search for the successful psychopath. Journal of Research in Personality, 44(4), 554-558. Doi:10.1016/j.jrp.2010.05.010.

[31]. Harms, P. D., \& Wood, D. (2016). Stress, well-being, and the dark side of leadership. The Role of Leadership in Occupational Stress (Research in Occupational Stress and Well-Being), 14, 33-59. Doi:10.1108/S1479355520160000014002 .

[32]. Hart, W., Adams, J., Burton, K. A., \& Tortoriello, G. K. (2017). Narcissism and self-presentation: Pro fi ling grandiose and vulnerable Narcissists , self-presentation tactic use. Personality and Individual Differences, 104, 48-57. Doi:10.1016/j.paid.2016.06.062.

[33]. Hart, W., \& Adams, J. M. (2014). Are narcissists more accepting of others , narcissistic traits? Personality and Individual Differences, 64, 163-167. Doi: 10.1016/j.paid.2014.02.038.

[34]. Hart, W., Adams, J. M., \& Burton, K. A. (2016). Narcissistic for the People: Narcissists and non-narcissists disagree about how to make a good impression. Personality and Individual Differences, 91, 69-73.

Doi:10.1016/j.paid.2015.11.045

[35]. Henfrey, S. A. (2018). Kaizen : Working responsively with psychopathic traits. Journal of Criminological Research Policy and Practice, 4(3), 199-211. Doi:10.1108/JCRPP-11-20170034.

[36]. Hill, D., \& Scott, H. (2019). Climbing the corporate ladder: Desired leadership skills and successful psychopaths. Journal of Financial Crime, 26(3), 881896. Doi:10.1108/JFC-11-2018-0117.

[37]. Hobson, J. L., Stern, M. T., \& Zimbelman, A. F. (2019). The benefit of mean auditors: The influence of social interaction and the dark triad on unjustified auditor trust. Contemporary Accounting Research. 37(2), 1217-1247. Doi: 10.1111/1911-3846.12511.

[38]. Jain, K., \& Bearden, J. N. (2011). Machiavellianism and overconfidence. INSEAD Working Paper No. 2011/29/DS, 1-23. Doi: $10.2139 /$ ssrn. 1774523 .

[39]. Jeppesen, K. K., \& Leder, C. (2016). Auditors ' experience with corporate psychopaths. Journal of Financial Crime, 23(4), 870-881.

[40]. Johnson, E. N., Kuhn, J. R., Apostolou, B. A., \& Hassell, J. M. (2013). Auditor perceptions of client narcissism as a fraud attitude risk factor. AUDITING: $A$ 
Journal of Practice \& Theory, 32(1), 203-219. https://doi.org/10.2308/ajpt50329

[41]. Jonason, P. K., Webster, G. D., Schmitt, D. P., Li, N. P., \& Crysel, L. (2012). The antihero in popular culture: Life history theory and the dark triad personality traits. Review of General Psychology, 16(2), 192-199. Doi:10.1037/a0027914.

[42]. Jones, D. N. (2013). Psychopathy and machiavellianism predict differences in racially motivated attitudes and their affiliations. Journal of Applied Social Psychology, 43(SUPPL.2), 367-378. Doi:10.1111/jasp.12035.

[43]. Kan, M. P. H., Fabrigar, L. R., \& Fishbein, M. (2017). Theory planned of behaviour. In book Encyclopaedia of Personality and Individual Differences, 1-8. Doi:10.1007/978-3-319-28099-8.

[44]. Mahaffey, K. J., \& Marcus, D. K. (2006). Interpersonal perception of psychopathy: A social relations analysis. Journal of Social and Clinical Psychology, 25(1), 53-74. doi:10.1521/jscp.2006.25.1.53.

[45]. Maibom, H. L. (2005). Moral unreason: The case of psychopathy. Mind and Language, 20(2), 237-257. Doi:10.1111/j.0268-1064.2005.00284.x.

[46]. Mathieu, C., Neumann, C. S., Hare, R. D., \& Babiak, P. (2014). A dark side of leadership: Corporate psychopathy and its influence on employee well-being and job satisfaction. Personality and Individual Differences, 59, 83-88. Doi:10.1016/j.paid.2013.11.010.

[47]. Morf, C. C., \& Weir, C. (2000). Narcissism and intrinsic motivation : The role of goal congruence. Journal of Experimental Social Psychology, 36(4), 424-438. Doi:10.1006/jesp.1999.1421.

[48]. Mullen, P. D., Hersey, J. C., \& Iverson, D. C. (1987). Health behaviour models compared. Social Science and Medicine,
24(11), 973-981. Doi:10.1016/02779536(87)90291-7.

[49]. Murphy, P. R. (2012). Attitude, Machiavellianism and the rationalization of misreporting. Accounting, Organizations and Society, 37(4), 242259. doi:10.1016/j.aos.2012.04.002

[50].

[51]. Murugesan, R., \& Jayavelu, R. (2015). Testing the impact of entrepreneurship education on business, engineering and arts and science students using the theory of planned behaviour. Journal of Entrepreneurship in Emerging Economies. 7(3), 256-275. Doi:10.1108/JEEE-12-2014-0053.

[52]. Osumi, T., \& Ohira, H. (2010). The positive side of psychopathy: Emotional detachment in psychopathy and rational decision-making in the ultimatum game. Personality and Individual Differences, 49(5), 451-456.

Doi:10.1016/j.paid.2010.04.016.

[53]. Paleczek, D., Bergner, S., \& Rybnicek, R. (2018). Predicting career success: Is the dark side of personality worth considering? Journal of Managerial Psychology, 33(6), 437-456. Doi:10.1108/JMP-11-2017- 0402.

[54]. Perry, J. L. (2015). Revisiting the core of our good government ethos. Public Administration Review, 75, 186-187. Doi:10.1111/puar.12350.

[55]. Pletti, C., Lotto, L., Buodo, G., \& Sarlo, M. (2017). It's immoral, but I'd do it! Psychopathy traits affect decisionmaking in sacrificial dilemmas and in everyday moral situations. British Journal of Psychology, 108(2), 351-368. Doi:10.1111/bjop.12205.

[56]. Raskin, R., \& Hall, C. S. (1981). The narcissistic personality inventory: Alternative form reliability and further evidence of construct validity. Journal of Personality Assessment, 45(2), 62-159. Doi: 10.1207/s15327752jpa4502_10. 
[57]. Rest, J. R. (1984). Research in moral development: Implication for training counselling psychologist. The Counselling Psychologist, 12(3), 19-29.

[58]. Rose, P. (2002). The happy and unhappy faces of narcissism. Personality and Individual Differences, 33(3), 379$392 . \quad$ Doi: 10.1016/S01918869(01)00162-3.

[59]. Ruiz-Palomino, P., Bañón, A., Jorge, G., \& Langreo, L. (2018). Impacts of peers , unethical behaviour on employees, ethical intention : Moderated mediation by Machiavellian orientation. Business Ethics: The Environment \& Responsibility, 28(2), 185-205. Doi: 10.1111/beer.12210.

[60]. Sandvik, A. M., Hansen, A. L., Johnsen, B. H., \& Laberg, J. O. N. C. (2014). Personality and Social Psychology Psychopathy and the ability to read the "language of the eyes": Divergence in the psychopathy construct. Scandinavian Journal of Psychology, 55(6), 585-592. Doi:10.1111/sjop.12138.

[61]. Shafer, W. E. (2009). Ethical climate , conflict and organizational commitment: A study of Chinese auditors. Accounting, Auditing \& Accountability Journal, 22(7), 10871110.

Doi:10.1108/09513570910987385.

[62]. Shafer, W. E., \& Simmons, R. S. (2008). Social responsibility, machiavellianism and tax avoidance: A study of Hong Kong tax professionals. Accounting, Auditing \& Accountability Journal, 21(5), 695-720. Doi:10.1108/09513570810872978.

[63]. Shafer, W. E., \& Wang, Z. (2010). Effects of ethical context on conflict and commitment among Chinese accountants. Managerial Auditing Journal, 25(4), 377-400. Doi:10.1108/02686901011034180.

[64]. Shafer, W. E., \& Wang, Z. (2018). Machiavellianism, social norms and taxpayer compliance. Journal of Chemical Information and Modelling, 53(9), 1689-1699. doi:10.1017/CBO9781107415324.004.

[65]. Shafer, W. E., Morris, R. E., \& Ketchand, A. A. (2001). Effects of personal values on auditors' ethical decisions. Accounting Auditing \& Accountability Journal, 14(3), 254-277. Doi: 10.1108/EUM0000000005517.

[66]. Smith, P. C., McTier, K., \& Pope, K. R. (2009). Non-profit employees’ machiavellian propensities. Financial Accountability \& Management, 25(3), 335-352. Doi:10.1111/j.14680408.2009.00480.x.

[67]. Smith, S. F., \& Lilienfeld, S. O. (2013). Psychopathy in the workplace: The knowns and unknowns. Aggression and Violent Behaviour, 18(2), 204-218. Doi:10.1016/j.avb.2012.11.007.

[68]. Sr, D. F. A., \& Virginia, W. (2013). Internal and external auditor ethical decision-making. Managerial Auditing Journal, 28(4), 300-322. Doi:10.1108/02686901311311918.

[69]. Tonge, A., Greer, L., \& Lawton, A. (2003). The Enron story: You can fool some of the people some of the time. Business Ethics: A European Review, 12(1), 4-22.

[70]. Triki, A., Cook, G. L., \& Bay, D. (2017). Machiavellianism, moral orientation, social desirability response bias, and anti-intellectualism: A profile of Canadian accountants. Journal of Business Ethics, 144(3), 623- 635. Doi:10.1007/s10551-015-2826-7.

[71]. Tucker, R. L., Lowman, G. H., \& Marino, L. D. (2016). Dark triad traits and the entrepreneurial process: A person- entrepreneurship perspective. Research in Personnel and Human Resources Management, 34, 245-290. Doi:10.1108/S0742730120160000034013. 
[72]. Utami, I., Astiti, Y. W., \& Mohamed, N. (2019). Fraud intention and machiavellianism: An experimental study of fraud triangle. International Journal of Financial Research, 10(5), 269-279. Doi:10.5430/ijfr.v10n5p269.

[73]. Vandekerckhove, W., \& Cremer, D. D. (2019). Managing unethical behaviour in organizations: The need for a behavioural business ethics approach. Journal of Management \& Organization, 23(3), 437-455.

Doi:10.1017/jmo.2016.4.

[74]. Veres, J. C., Eva, N., \& Cavanagh, A. (2019). “ Dark " student volunteers: Commitment , motivation and leadership. Personnel Review, 49(5), 1176-1193. Doi: 10.1108/PR-02-20190085.

[75]. Wales, W. J., Patel, P. C., \& Lumpkin, G. T. (2013). In Pursuit of Greatness: CEO Narcissism , Entrepreneurial Orientation, and Firm Performance Variance. Journal of Management
Studies, 50(6), 1041-1069. Doi: 10.1111/joms.12034.

[76]. Wright, B. E. (2014). Does ethical leadership matter in government? effects on organizational commitment, absenteeism, and willingness to report ethical problems. Public Administration Review, 74, 333-343. Doi:10.1111/puar.12216.

[77]. Young, H. M., Lierman, L., Powell-Cope, G., Kasprzyk, D., \& Benoliel, J. Q. (1991). Operationalizing the theory of planned behaviour. Research in Nursing \& Health, 14(2), 137-144. Doi:10.1002/nur.4770140208.

[78]. Yzer, M. (2017). Theory of reasoned action and theory of planned behaviour. The International Encyclopedia of Media Effects, 1-7. Retrieved online from https://onlinelibrary.wiley.com/doi/abs/1 0.1002/9781118783764.wbieme0075. 